\title{
Residential tourism and environmental dynamics in Acapulco, Guerrero, Mexico: Case study "Las Palmas"
}

\author{
Turismo residencial y dinámica ambiental en Acapulco, Guerrero, México: Estudio \\ de caso "Las Palmas"
}

\author{
NIÑO-CASTILLO, Jacob Elías †*, DIMAS-MOJARRO, Juan José, NIÑO-GUTIÉRREZ, Naú Silverio \\ and NIÑO-CASTILLO, Isaías Naú
}

Universidad Autónoma de Guerrero, Faculty of Tourism. Mexico.

ID $1^{\text {st }}$ Author: Jacob Elías, Niño-Castillo / ORC ID: 0000-0002-0575-5336, CVU CONACYT ID: 919977

ID $1^{\text {st }}$ Co-author: Juan José, Dimas-Mojarro / ORC ID: 0000-0003-1815-5580, CVU CONACYT ID: 479593

ID $2^{\text {nd }}$ Co-author: Naú Silverio, Niño-Gutiérrez / ORC ID: 0000-0001-9250-0798, Researcher ID Thomson: W-2654-2017, CVU CONACYT ID: 32380

ID $3^{\text {rd }}$ Co-author: Isaías Naú, Niño-Castillo / ORC ID: 0000-0003-0728-3798, CVU CONACYT ID: 919978

DOI: $10.35429 / J A F .2020 .21 .7 .17 .23$

Received July 20, 2020; Accepted December 30, 2020

\begin{abstract}
The central purpose of this study was to expose in a synthesized way the characteristics of residential tourism and environmental dynamics in the housing subdivision "Las Palmas" of Acapulco, Guerrero, Mexico. The applied methodology consisted of cabinet and field work, that included participant observation and application of 600 questionnaires to residents and residential tourists, this questionnaire was formed by 14 items. Results: $a$ ) an updated plan map of "Las Palmas", $b$ ) characterization of the local residential tourism, $c$ ) environmental dynamic of the studied area and $d$ ) diagnosis of environmental character and residential tourism at an infra-local level. Conclusions: 1) second homes involves: $a$ ) the tourist as consumer of the house; $b$ ) the real estate market that offers in an attractive way this beach as destination and $c$ ) the entailment between the emitting and receiving space through "el Sol" highway (Cuernavaca-Acapulco); 2) use of the soil change from agriculturist to residential, has brought the modification of habitats; migration of birds and minor coverage of low deciduous forest and 3) "Las Palmas" represented favorable economic balances for real estate with the detonation of residential tourism through the West of the center of Acapulco.
\end{abstract}

Enviroment, Territorial analysis, Residential tourism

\begin{abstract}
Resumen
El objetivo central del estudio fue exponer de manera sintetizada las características del turismo residencial y la dinámica ambiental en la unidad habitacional "Las Palmas" de Acapulco, Guerrero, México. La metodología aplicada consistió en trabajo de gabinete y campo que comprendió a la observación participante y aplicación de 600 cuestionarios a residentes y turistas residenciales, dicho cuestionario se integró por 14 ítems. Resultados: $a$ ) mapa actualizado de la traza del "Las palmas", b) caracterización del turismo residencial local, $c$ ) dinámica ambiental en el área en estudio y $d$ ) diagnóstico de carácter ambiental y del turismo residencial a nivel infra-local. Conclusiones: 1) La segunda residencia articula: a) el turista como consumidor de la vivienda; $b$ ) el mercado inmobiliario que oferta de manera atractiva este destino de playa y $c$ ) la vinculación entre el espacio emisor y receptor a través de la Autopista del Sol (Cuernavaca-Acapulco); 2) con el cambio en el uso del suelo de agrícola a residencial trajo consigo la modificación de hábitats; migración de avifauna y menor cobertura de selva baja caducifolia y 3 ) "Las Palmas" representó saldos económicos favorables para la inmobiliaria al detonar el turismo residencial al occidente del centro de Acapulco.
\end{abstract}

Ambiente, Análisis territorial, Turismo residencial

Citation: NIÑO-CASTILLO, Jacob Elías, DIMAS-MOJARRO, Juan José, NIÑO-GUTIÉRREZ, Naú Silverio and NIÑOCASTILLO, Isaías Naú. Residential tourism and environmental dynamics in Acapulco, Guerrero, Mexico: Case study "Las Palmas". Journal of Administration and Finance. 2020. 7-21:17-23.

\footnotetext{
* Correspondence to Author (Email: aneicasni4@gmail.com)

$\dagger$ Researcher contributing first author.
} 


\section{Introduction}

Worldwide panorama experiences social and economic modifications that affect tourism directly, which leads to territorial, environmental, and cultural recategorization as a sustenance of policies oriented towards the development at a local level. In recent years, massive tourism has been promoted, as well as the distribution of the supply and demand for this activity. An excellent factor is the increase in the construction of residences intended to be second homes in tourist destinations that have tropical climate, beach, routes of communication, public infrastructure (SPT, 2015), services, quality of life, among other aspects.

Mexico, like other Latin American countries, suffers signs of alteration of the natural landscape associated with poverty, loss of renewable resources, pollution, and the change of soil use, which is shown in the massive construction of housing subdivisions. The importance of sustainability involves the observation of diverse elements, now in dispute between the different regions from the country since the financial factors repel in the natural ones. Residential tourism requires of diverse sciences for its study, since in the tourist surroundings different environmental, social, cultural, governmental, and economic paradigms come together (Cardinal, 2020).

Guerrero's state has high physicalbiological wealth, due to its wild biodiversity and spaces; within the territory it counts on infrastructure, tourist services, as well as routes of communication, that establishes contact between the main cities: Acapulco de Juárez, Iguala, Ixtapa-Zihuatanejo and Taxco. Acapulco is an essential economic enclave; its activities turn around the national and international tourism, which has generated excessive growth of the urban footprint, loss of habitats, channel clogging, among others. This municipality has a surface of $1882,60 \mathrm{~km}^{2}$; which represents $2,9 \%$ of the state's surface It lies to the north with the municipalities of Chilpancingo and Juan R. Escudero, to the south with the Pacific Ocean, to the east with San Marcos and to the west with Coyuca de Benítez (INEGI, 2017).
The analysis of the area oriented to second homes can be approached from a geographic perspective to understand the conjuncture of the system, which is integrated by three subjects: a) the tourist as the one who arrives to the location (purchaser); $b$ ) agents who operate the real estate offer, and $c$ ) the tourist destination and infrastructure (emittingreceiving relation) (Vera et al, 1997 \& Boullón, 1997).

From this perspective, the arrival of individuals to second homes tourist sites has a space and social connotation, that helps in the understanding of how the destination is selected to carry out leisure activities (perception), the acquisition of a second residence (symbolism), in addition to the diverse relations with the local population (social networks). The increase of real estate's market has transformed the rural provinces into urban, when accentuating the number of residents, mobility, and modernization (Xue et al; 2017).

In this process four elements take part: $I$ ) the consumers, tourist promoters, II) real estate groups, III) communication routes, and $I V$ ) the surroundings as attraction element, where sun and beach tourism are the most frequent way of growth (Pearce, 1988; figure 1). From this dynamic, urban expansion of the coastal regions became uncontrollable, due to the touristic impulse and arrival of a greater number of visitors (Benseny, 2006). This resulted on a greater demand of land trading for different aims; nevertheless, the acquisition of agricultural grounds, in addition to some administrative problematics, forged a real estate speculation (McCabe \& Qiao, 2020). 


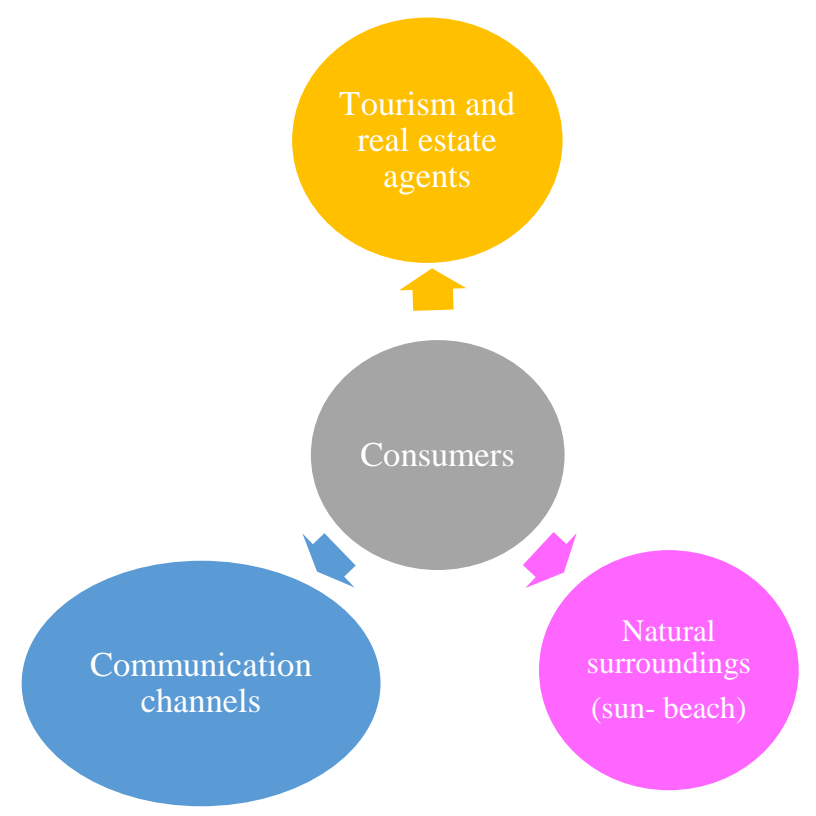

Figure 1 Elements that integrate residential tourism Source: Pearce, 2014; modified by authors

\section{Methodology}

The main purpose was to generate a holistic study that would integrate the effects of urbanization and the current dynamics of second homes in "Las Palmas" housing unit into the natural environment. For this reason, four phases were completed in the systematic research process related to the environmental, social, tourist and geographical subsystems, composed by the characterization of the materials, population-type-sampling delimitation, used techniques, and creation of situational analysis. In another aspect, the approach used was mixed, due to the management of qualitative and quantitative variables from a sustainable perspective.

The scope was analytical with a nonexperimental typology, which is conceptualized as research, study or case that is carried out without intentionally modifying the elements, factors, or variables. The above points out that the phenomenon is seen as such for its study, the researcher cannot exert any direction or action on them; the individual variants have already been raised and cannot be altered, nor their results (Hernandez et al., 2003).
As a result, it was necessary to use an information-gathering tool to obtain a deeper picture of the local reality. This required documentary compendiums related to residential tourism precedents. There is a clear convergence of views highlighting the development of a systematic conceptual and methodological approach in the research of urban systems, determined by the tourist-natural subsystems, which establishes geographical limits, defining their characteristics and dimensions according to the selected categories.

To this end, written, formal and informal articles were consulted (documentary materials, web pages, statistical data query, geographic charts, orthophotos, among others), also resorted to direct observation and questionnaires, which complement the local characterization. By following a deductive and inductive methodology, a cross-sectional analysis was required. The design used was the transactionalcorrelational, which addresses and details the relationships between variables in each period or by cause-effect, based on the guiding question, when considering the scope of the study (Hernandez et al., 2003). However, this document relates variables without considering direction and causality analysis.

The methodologic process consisted in the following global actions: Cabinet work, including the analysis and consultation of literature specialized in tourism, residential tourism, second homes, socio-territorial segregation (Niño, 2017), lodging types, local environment, among others, complemented by dissemination literature. To do this, they were used search engines, academic databases, virtual libraries, as well as the map library of the Honorable Ayuntamiento Municipal de Acapulco. In addition, it was revised the digital and printed cartography of the city where it was produced: $a$ ) the base map of the housing complex $b$ ) the processing of statistical databases; and $c$ ) the final drafting of the document and field work, based on location theory, fed back with direct observation (Babbie, 2000). 
It covered 30 exploratory visits and equipment verification from December 2018 to February 2020, within which were included $I$ ) an update of the cartographic location of the "Y""Z" condominiums, formerly territorial/commercial reserve, II) photographs of facilities, infrastructure, and aspects of the complex, as well as III) the application of questionnaires to owners and second home tourists. The written tool used to measure residential tourism and environmental dynamics was in line with the guidelines established by the Sustainable Development Goals (SDG), which were divided into: tourism, natural, social, and economic. They were chosen as closed sampling units 14 items that integrated the questionnaire designed and applied locally.

\section{The American Psychological} Association (APA) defines sample as a subset of the population, number of elements or subjects which compose it (APA, 2016). It is representative because it has a level of reliability and margin of error, which allows inferring possible results. Its advantage is in reducing costs in different aspects (economic, labor and material). It allows data collection in less time; furthermore, it makes it possible to study large populations. Its typology is divided into two parts: the finite, formed by a limited number of elements; and the infinite, composed of an extremely large number of components.

Therefore, for this research, a sample is defined as the population of residents and tourists, who were selected for the purpose of obtaining representative information (Niño, 2018). The sampling process required mathematical formulas to offer greater theoretical-scientific rigor, since the present study is based on a mixed approach; the use of a structured questionnaire to determine the several problems of residential tourism inside and outside the "Las Palmas" housing unit was important; it should also be noted that the obtained results are representative.

The used sampling typology was stratified probabilistic, since it proportionally adjusts the existing elements with the population, the presence of one of them in some stratum discards it from another. This method improves accuracy and includes the use of different sizes, to reduce the variations of each sample unit (Hernandez et al., 2003).
In this research the answers were divided into two categories: yes or no. The sample consisted of 436 participants, of whom 98 belong to local habitants and 338 to tourists who have a second home in the housing subdivision, the participants were chosen according to the following criteria: Gender: indistinct; age: 18 years and older; Geographic location: Housing subdivision "Las Palmas", Tunzingo, Acapulco, Guerrero, and socioeconomic conditions: Middle-class.

\section{Results}

The results of the questionnaires are presented below; for this purpose, it was decided to show them in three blocks of five questions with their respective answers, with percentage and in blue for the positive answers (yes), and in orange negative answers (no). It is worth mentioning that the questions will appear in descending order. Regarding question two, the residents and tourists answered that by the moment they bought the property they did not know in what year the construction of the complex began, which matches with the answer to question four, that shows that $90 \%$ of the owners have suffered floods in their property because of tropical storms named Henriette, 2007 and IngridManuel, 2013 very similar to what is staed by (Student et al, 2020).

An important term is tourism gentrification, related to the applied questionnaire that alludes the process in which visitors tend to "displace" residents, since agricultural land was divided by lots for residential purposes, as it happened in the area under study since 1999 to the present, and it is even seen that "tourism growth of (seconds homes) affects the market of local housing" (Cocola, 2018:287). Since agricultural land is now priced at 200 dollars per square meter.

The second part of the questionnaire (questions 6 to 10) relates to the minimum services that a housing unit of social interest (McCabe \& Qiao, 2020) must have, where 34\% replied that they do. However, when asked if they were aware of the territorial problems of the housing unit with the City Council, 90\% said they were unaware of the problem; on the other hand, $45 \%$ does not agree with the current administration of "Las Palmas" (figure 2). 
It should be noted that the members of the current Administration only modify their corporate name every year from 2006 to the present, although they are now aware of the floods that during the rainy season affect the population's patrimony.

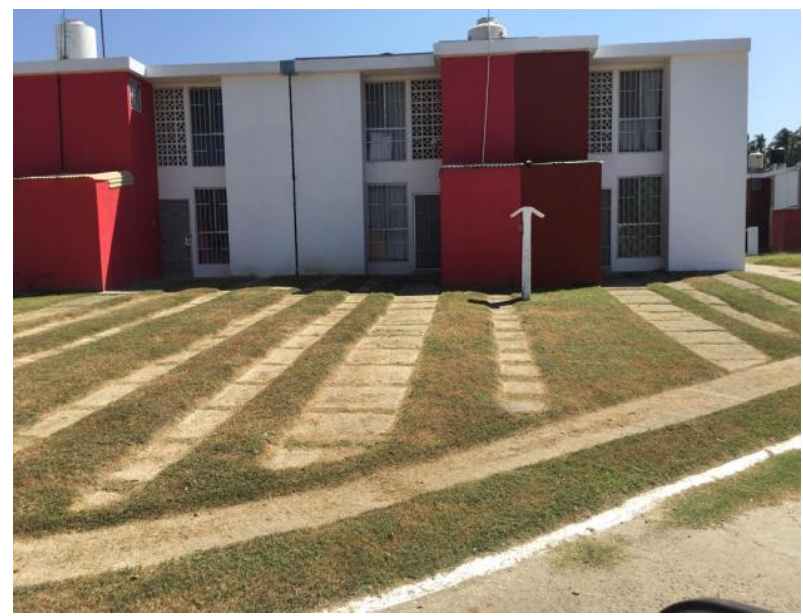

Figure 2 House typology

Source: Courtesy, Jacob Niño

The third part (questions 11 to 14) refers to the current infrastructure of the access road, where 75 per cent of respondents expressed that they do not approve the conditions in which they currently live; In addition, $60 \%$ do not know the location of the two sewage suction chambers of the housing subdivision. $90 \%$ of those interviewed disagrees with the proposal of adding the waste of Tunzingo's residents and the nearby convenience store (Oxxo) to the sewage of the housing subdivision. $70 \%$ of the residents who were asked if they were satisfied with the television, internet and telephone services provided by Teléfonos de México (Telmex), since it is the only provider accepted by the members of the current Executive Committee of Administration, responded to be dissatisfied, while only $30 \%$ were satisfied.

Regarding the geographical approach and this infra-local space, the proposals of Wijkman and Timberlake (1986:27), who established several reasons why there are more disasters in developing countries rather than in developed ones, due to human vulnerability because of poverty and social inequality, environmental degradation (Rodríguez, 2018) caused by change of soil use and intensification caused by population growth, especially of the most vulnerable (Niño, 2018).
As a result of this dynamic, urban growth in Tunzingo is overwhelming because residents in general are increasing as a result of the polarization of initiatives and jobs. In such a way that there is population pressure on the neighboring land to the housing subdivision, due to demographic growth that develops towards the west by the resident population in Cayaco, and to the east by the municipality of San Marcos. The population dedicated to service activities is increasing (tertiary), and secondary in some cases. Therefore, the employment decrease in agricultural activities contributes to the disarticulation and abandonment of primary activities (Aguilar, 2009:36-52).

Agricultural and livestock activities have become less important because of the low cost of unprocessed products from the countryside, hence the inhabitants of Tunzingo leave or sell their family orchards over time. Something that draws attention, is the role and functions of local transport that has passed from an unproductive and parasitic tertiary activity, to a microprocess generating profits, and even, it is used by the government as a political enabler to keep in power the character or the political party, as it best suits to the government at a given time (Camarena, 1989 and Chías, 1993).

According to the mentioned problematic, the socio-territorial analysis applied to the housing subdivision "Las Palmas", the tourists who chose to acquire one of the 803 houses for their leisure moments and vacations, in some cases prefer to rent their buildings per day or month, in order to obtain an economic benefit, as it happens at the moment in the study area. It should be borne in mind that, on numerous occasions, such rental is not registered to avoid taxes payment in the municipality, which represents serious problems for the correct accounting of this type of tourism.

Residential tourism in the housing subdivision is in the process of gentrification, which is expressed in the existence of swimming pools as well-established public's spaces, which results in a process of social escalation. Since there are more services such as paved streets, sidewalks, green areas in each horizontal condominium, maintenance of sidewalks, the well of water, sewage suction chambers in addition to the numerous luminaires, private telephone-television cabling (Tomej \& Xiang, 2020).

NIÑO-CASTILLO, Jacob Elías, DIMAS-MOJARRO, Juan José, NIÑO-GUTIÉRREZ, Naú Silverio and NIÑO-CASTILLO, Isaías Naú. Residential tourism and environmental dynamics in Acapulco, Guerrero, Mexico: Case study "Las Palmas". Journal of Administration and Finance. 2020 
All this increases the economic value of the second home, and it is precisely for this reason that individuals and families (Torkington \& Perdigao, 2020) with sufficient economic resources consider the housing subdivision as a good place to buy one or more houses. The type of construction was bought by a middle-high socioeconomic sector with social interest value. The type of settlement is summarized in the information of the dwelling and its services: drainage, electricity, and piped water. The housing density is of 40 houses on average per horizontal condominium, the minimum lot size is $120 \mathrm{~m}^{2}$ and the age of the unit is 20 years to this date.

\section{Thanks}

We are grateful for the financial support provided by the Scholarship of the National Council of Science and Technology (Conacyt) for the development of thesis research in the Master of Science: Sustainable Tourism Management of the Autonomous University of Guerrero (August 2018-July 2020) is appreciated.

\section{Conclusions}

Second homes are a complex issue that required geographical optics to contemplate the interrelation and articulation of the parties involved: a) the tourist as home consumer; b) the real estate market that attractively offers this beach destination and c) the link between the sending and receiving space through the del Sol highway with which time and effort in the journey is reduced.

Concerning the proposed methodology, it was possible to satisfactorily achieve the presented objective by identifying, characterizing, and analyzing the components of the habitational subdivision under study. Among other results it was obtained that with the soil use chain from agricultural to residential brought the destruction of habitats, transformation of the natural landscape; loss of biodiversity; migration of birdlife and less coverage of low deciduous forest.
The construction of the housing subdivision "Las Palmas" represented favorable economic balances for the members of the Real State, but the residents were bequeathed with periodic flood problems, which means negative aspects, since they represent expenses for the restoration and maintenance of the houses and real estate, but the diagnosis of the studied area revealed that of 24 condominiums that integrate the housing subdivision, only nine maintain their original facade the rest (15) have been modified over time, interest and economy of their owners many of them due to residential tourism.

\section{References}

Aguilar, A. (2009). Urbanización periférica e impacto ambiental. El suelo de conservación en la Ciudad de México en Aguilar, A. \& Escamilla, I. (coords). Periferia Urbana: deterioro ambiental y reestructuración metropolitana. Ciudad de México: Instituto de GeografíaUNAM-CONACYT-Miguel Ángel Porrúa-LXI Legislatura de la Cámara de Diputados.

APA Style (2016). Fórmula para calcular la muestra de una población. Available at: https://apastyle.apa.org/

Babbie, E. (2000). Fundamentos de la Investigación Social. México: International Thompsom Editores.

Camarena, M. (1989). Grandes rutas del espacio social en México. México: IIS-UNAM.

Cardinal, J. (2020). Sustainable development frictions: lifestyle migration on the coast of Jalisco, Mexico. Journal of Political Ecology, 27(1), 1052-1071. https://journals.uair.arizona.edu/index.php/JPE/ article/view/23215/22501

Chías, L. (1993). El transporte de alimentos en México: situación frente a la globalización de los mercados en Cocola, A. (2018). 17. Tourism gentrification. In Loretta Lees \& Martin Phillips (eds.). Handbook of Gentrification studies. Cheltenham: Eduard Elgar. Available at: https://books.google.com.mx/books'ht=es\&lr=e s\&lr=\&id

Delagadillo, J. L \& Torres F. (coords). Los sistemas de abasto alimentario en México. México: IIEC-IGG-PUAL. 
Hernández, R. \& Fernández, C. (2003). Metodología de la investigación. México, D.F.: McGraw-Hill.

INEGI. (2017). Anuario estadístico del estado de Guerrero. CDMX: INEGI.

McCabe, S. \& Qiao, G. (2020). A review of research into social tourism: Launching tha annals of tourism research curated collection on social Tourism. Annals of Tourism Research, 1(85), $1-19$. https://reader.elsevier.com/reader/sd/pii/S01607 38320302474?token=EFD7EE8366E5E8F6649 044DDDB6C4556DBB991BE1BFE236B7654 889BD7D70025958B4DB6BAB6B4B3F19352 C86405AA54

Niño, J. (2017). Análisis socioterritorial aplicado al "Fraccionamiento Las Palmas", Acapulco, Guerrero. Guadalajara: Universidad de Guadalajara.

Niño, J. (2018). Trabajo de Campo en el Fraccionamiento Las Palmas. Álbum fotográfico personal. Inédito.

Pearce, D. (2014). Destinos turísticos: conceptos e implicaciones para su gestión en tiempos de cambio. En López, F. (coord.). Turismo y territorio. Innovación, renovación y desafíos. Valencia: Tirant Humanidades.

Rodríguez, M. F. (2018). Cuantificación de vulnerabilidad y riesgo: las inundaciones en Motozintla de Mendoza, Chiapas, México. Revista Cartográfica, 1(97), 81-142. Available at: http://www.ipgh.org.

SPT. Secretaría de Protección Civil. (2015). Gaceta. Departamento de ingeniería estructural. Available at: http://www.proteccioncivilguerrero.gob.mx/pcg ro/Pdf/Gaceta_mayo2015.pdf

Student, J.; Kramer, M. \& Steinmann, P. (2020). Simulating emerging coastal tourism vulnerabilities: an agent-based modelling approach. Annals of Tourism Research 1(85), 117.

https://reader.elsevier.com/reader/sd/pii/S01607 3832030178X?token=4DA0337DA927FC8587 8822AE868B87F3C0581ACF119C3161C879B 38D200EBBEBEF864046CC5F3D80EFD11A 4123F974DB
Tomej, K. \& Xiang, Z. (2020). Affoordances for tourism services design. Annals of Tourism Research, 1(85), 1-9.

https://reader.elsevier.com/reader/sd/pii/S01607 38320301730?token=A387BFBE3F0D25C732 EB57541D54D3CAA23C4B92A5D6BE7605B 2AAA64F1CF4B44D7181A7B61FF80D24772 B688F4A9387

Torkington, K. \& Perdigao, F. (2020). Whose right to the city? An analysis of the mediatized politics of place surrounding alojamento local issues in Lisbon and Porto. Journal of Sustainable Tourism, AHEAD-OF-PRINT, 120.https://www.tandfonline.com/doi/epub/10.10 80/09669582.2020.1849230?needAccess $=$ true

Vera, F.; López, F.; Marchena, M. \& Antón, S. (1997). Análisis territorial del turismo. Una nueva geografía del turismo. Barcelona: Ariel.

Wijkman \& Timberlake. (1986). Natural Disaster. Acts of god or acts of man. London: Earthscan.

Xue, L.; Kerstetter, D. \& Hunt, C. (2017). Tourism development and changing rural identity in China. Annals of Tourism Research. 1(66), 170-182. Available at https://www.elsevier.com/locate/atoures 